\title{
Risk prioritization and selection of contractor participating in Public- Private Partnership (PPP) infrastructure project using Hybrid Fuzzy AHP and Fuzzy TOPSIS (Case Study: Saveh-Salafchegan Freeway Project)
}

\author{
Ebrahim Jokar $^{1 \text { (D) }}$, Babak Aminnejad ${ }^{* 2}$ iD , Alireza Lorak ${ }^{3}$ (D) \\ ${ }^{1}$ Islamic Azad University, Department of Civil Engineering, Kish International Branch, Kish Island, Iran \\ ${ }^{2}$ Islamic Azad University, Department of Civil Engineering, Rodehen Branch, Rodehen, Iran \\ ${ }^{3}$ Islamic Azad University, Department of Civil Engineering, Safadasht Branch, Safadasht, Iran
}

\begin{abstract}
Execution of infrastructure projects is considered as one of the most important indices of the country's economic growth and development. In these projects, the governments' financing always plays a vital role in the development and achieving project goals within the specified time. In order to deal with the problem, governments tend to increase the role of private sector companies in the development of infrastructure projects using public-private partnership (PPP) contracts. On the other hand, the private company should also be aware of the risks involved in the project, as well as the extent of the involvement of each of the risk factors in the overall project risk. To solve this issue, in this paper, the risk factors are first identified and then the proposed hybrid approach based on Fuzzy Analytical Hierarchy Process (AHP) and Fuzzy Technique for Order of Preference by Similarity to Ideal Solution (TOPSIS) is used to prioritize the risk factors and finally select the contractor company to implement the Saveh-Salafchegan Freeway Project.
\end{abstract}

\section{Keywords}

Saveh-Salafchegan Freeway PPP Project; Fuzzy AHP; Fuzzy TOPSIS; Risk prioritization

Received: 01 September 2019; Accepted: 29 January 2020

ISSN: 2630-5771 (online) (C) 2020 Golden Light Publishing All rights reserved.

\section{Introduction}

The execution of infrastructure projects is one of the most important indicators of developing countries' economic growth and development. There is also been a dramatic rise in the population and economic growth of developing countries. Therefore, there is an urgent need for developing infrastructures in most of these countries. Bringing this practice to Iran would cause shockwaves through the government system, which is firstly incredibly costly in their operations, secondly grossly underfunded, and highly wasteful use of resources. Also, one of the most important aspects of launching and developing infrastructure projects in Iran is the provision of financial support for them. This factor plays the most crucial role in developing and achieving project objectives within the specified time. Due to the limited budget allocated to infrastructure projects in Iran and the high costs of country management, it becomes clear that there is an urgent need for the financing of

\footnotetext{
Corresponding author

Email: aminnejad@riau.ac.ir
} 
infrastructure projects. To overcome this issue, the government is trying to participate in private-sector companies in the projects using the Public-Private Partnership (PPP) scheme. The PPP projects are executed with the participation of one or more private companies (with or without the government) [1]. In addition to the PPP financing benefits, The PPP projects can also transfer practical and useful experiences between public and private organizations. So, the PPP projects have several advantages over the normal projects, including access to the private sector experience and fund, risk transfer to the private sector, increased transparency and responsibility. The PPP projects also involve a wide range of potential risks, including economic risks, legal and political risks, environmental and social risks, technical risks [2]. These risks are usually created because of the nature of assets, initial costs, the complexity of the system, and the time duration of the investment. These Risk factors could significantly affect all phases of the PPP project's efficiency. In these projects, the organizations can also choose and adopt either avoidance, transfer, divide, or control strategies for project risk management. In avoidance strategy, due to its prior plans and the high-risk level in the PPP project, the company avoids participating in the project contract and then the organization must execute the project. However, In other strategies (transfer, divide, and control), the private companies involved in the project contract can estimate the total project risk and accordingly declare their readiness to execute part or all of the project. In other words, the contract is actually an organization's mechanism that identifies the rights and responsibilities of each of the participating companies in the assignment of rewards and risks as well as other requirements. Therefore, risk prioritization and project contractor selection are both crucial issues in achieving PPP project goals. As a result, Inappropriate risk prioritization and project contractor selection lead to ineffective project management, higher costs, more increasing disparities in the project and PPP project completion time [3]. To fix these both issues, the literature addresses a two-step approach, including 1) Identifying risk factors in the infrastructure PPP projects using expert evaluation and previous studies. 1) Then, gathering Experts' opinions using questionnaires and interviews to prioritize the risk factors and select the best contractor to execute the project. According to what was stated and with the aim of selecting the best private company to execute the project (with the lowest overall risk level), first of all, we will discuss the risk factors affecting the PPP infrastructure projects and then, we will thoroughly analyze the risk of Saveh-Salafchegan freeway PPP project using Fuzzy TOPSIS from the Private sector's perspective. In addition, Fuzzy TOPSIS has been definitely proved its capabilities for solving the problem of risk prioritization in the PPP projects in this context. Generally, in the PPP projects take consideration uncertainties about related risks such as political, economic, performance, etc. These considerations create a multiple-criteria decisionmaking (MCDM) risk prioritization problem from the perspective of the project executives company and PPP project experts and also helps us to choose the suitable executor private company for SavehSalafchegan freeway PPP project.

The current paper is organized as follows: In Section 2, we will review the risk factors of PPP infrastructure freeways and highways projects, and then utilization Fuzzy TOPSIS, and Fuzzy AHP in the MCDM problem. In Section 3, a two-step identification approach is firstly used to determine the most important risks affecting the PPP project, then the risk factors are prioritized by using analytical Fuzzy AHP, and lastly chosen the right candidate for the execution of the freeway PPP project. The simulation results of the proposed method on the case study project will also be illustrated in section 3. Finally, section 5 dedicated to the conclusions, limitations, and ideas for further research.

\section{Literature review}

\subsection{Survey on PPP infrastructure projects}

The infrastructure is defined as the fundamental facilities and systems serving a country, city, or 
another area, including the services and facilities necessary for its economy to function [4]. Freeways are a type of infrastructure that is essential for the functioning of the modern industry. The Organisation for Economic Cooperation and Development (OECD) [5] defines a freeway as a road where all lanes are separated, no at-grade junctions exist along their lanes, and all intersections are grade separation junctions. construction of freeways reduces the distance and ultimately the time needed to travel between cities. Due to the various risk factors involved in the construction of the freeway, there is a need to calculate the importance weight of each factor, and then estimate the overall project risk so that a suitable candidate can be selected to execute the freeway project. each of them should be identified to estimate the overall project risk so that a suitable candidate can be selected to execute the freeway project. In the following, there are presented some of the important and vital risk factors that have investigated in the research literature on the PPP project risk management.

In recent years, PPP projects have significantly attracted the attention of researchers and industrial decision-makers. For instance, in [6-7] hybrid approaches based on Fuzzy AHP for risk assessment and a synthesis Fuzzy assessment method for prioritizing risks of a PPP freeway project in China has been proposed. Also, in [8] has proposed a risk assessment model for highway projects using the jack-knife technique. Furthermore, the Analytical Network Process(ANP) method has been practically used in [9-10] for risk assessment of the subway system and EPC refinery projects in Iran, respectively. Also, having a PPP model for freeway project management can also improve its constructional, operational risks and benefits [11]. Therefore, the adoption of attractive support policies for the private sector could increase the number of PPP infrastructure projects, especially freeways and highways. For instance, in [12] introduced financial, economic, social and environmental risks as the main risk factors for an annual received profit model of the private sector but no risk assessment model has been provided. In addition to, in [13] a PPP project for building two bridges in the Lusoponte, Portugal has been studied and social, basic, economic, environmental, political and technical risks have been identified as the main risks of the PPP project but, again, no model has been presented for assessment of the overall risk level and selection of the appropriate company using Multi-criteria decision-making (MCDM) methods. MCDM methods rank potential candidates for the problem and then select the best candidate among them. It seems that the MCDM approach is suitable for managing complex risk factors in various aspects such as political, economic, social, and technical aspects of the project, as well as the risk assessment for all available candidates. In recent years, there have been many studies in the field of providing MCDM techniques such as TOPSIS and AHP. The TOPSIS and the AHP approach used as the most common methods of MCDM. The reason for this is its simplicity and as well as less sensitivity in the results [14]. However, In MCDM problems, it could be found two difficulties:1) imprecise defining the decision issue. 2) imprecise defining the decision-maker preference. The reason for this situation can be the lack of precise determination of risk factors of realization by analyzed variants and uncertainty in the expert's opinions. In order to handle these uncertainties in the decision process, the fuzziness definition of the decision matrix should be required in the classical AHP and TOPSIS methods [15]. Specifically, in [16] is presented fuzzy TOPSIS-based scenario analysis to prioritize and compare available candidates for the recycling process of solid municipal waste. Furthermore, there have been many studies on the successful application of fuzzy TOPSIS, including the ranking sustainable management of acid rain [17], assessment of safety and health risks for mining workers to effectively manage the uncertainties in the project [15], and supply chain risk management [18]. Also, there have been numerous studies conducted in the context of the application of fuzzy AHP such as assessment and allocation of risk in a freeway [4] and highway [5] 
PPP projects in China. Also, in [19] is shown that AHP depends on numerical judgment while assessment of project risk level using numerical judgments is not an easy job due to the uncertain nature of risks and lack of precise information. They have made use of the fuzzy logic theory for dealing with this problem.

Considering these studies, it can be concluded that researchers have extensively used a combination of Fuzzy logic theory and classical AHP and TOPSIS methods for risk prioritization and assessment of PPP infrastructure projects. Despite the popularity of MCDM techniques such as Fuzzy TOPSIS and Fuzzy AHP, finding a paper that focuses on risk assessment in PPP freeway and highway projects in Iran, while using a combination of fuzzy TOPSIS and fuzzy AHP techniques, and also takes uncertainties of the problem into consideration is very hard. Therefore, To fill this research gap while the capabilities of the fuzzy AHP and fuzzy TOPSIS methods, this paper purposes a hybrid method for prioritizing risk factors and selecting the best candidate for the execution of Saveh-Salafchegan freeway PPP Project.

\subsection{Risk factors of PPP infrastructure projects}

The first stage in risk prioritization and appropriate candidate selection for executing projects is the identification of potential risks in the projects. Therefore, Identification of important risk factors for overall risk level assessment in PPP freeway and highway projects using extensive literature review is firstly done and then, the list of factors is modified or completed using expert's opinions. In the initial stage, a 24-item list of identified risks produced from the literature review is presented in Table 1. Then, using expert's opinions, important risk factors for PPP freeway and highway projects in Iran are identified, corrected or completed.

Table 1. A list of main 4 risks and 24 sub-criteria extracted from earlier studies

\begin{tabular}{ll}
\hline Main criteria & Sub criteria \\
\hline & Basic risk [11] \\
Basic and political risks & Government funds [7] \\
& Covernment interference [23] \\
& Policies [24] \\
\hline & Financial risk [25] \\
& Market [26] \\
& Financing [27] \\
& Inflation [23] \\
& Exchange rate fluctuations [25] \\
& Interest rate fluctuations [25] \\
& Income [26] \\
Economic risk & Payment [25] \\
& Lack of supporting equipment [7] \\
& Risk of making profits to the detriment of people [11] \\
& Environmental risk [25] \\
& Quick delivery of the project [24] \\
& Construction risk [26] \\
& Performance [24] \\
Environmental and social risks & Finishing the project [11] \\
& Project operations [24] \\
& Delays [11] \\
& Contract changes [25] \\
& Project uniqueness [11]
\end{tabular}




\section{Materials and methodology}

\subsection{Organization of the study}

Fig. 1 shows the freeway project's risk prioritization and alternative selection framework organization provided in the current study. The approach includes the following stages: identification and prioritization of 24 risks existing in Saveh-Salafchegan Freeway PPP Project in Iran using a two-step questionnaire of literature review and views of project experts; selecting assessment criteria and determining risk weights using Fuzzy AHP; and assessment of risk level of private sector companies nominated for project execution and prioritizing them using Fuzzy TOPSIS. The data used in the present study are collected from interviews with project experts and archived records. The experts interviewed had to have 1) practical knowledge of private-sector transportation PPP projects, and 2) at least one year of experience working in risk assessment of transportation PPP projects. Based on these two requirements, 30 experts were selected to be interviewed and some information about them is provided in Table 2. So, in the process of this study, the project risks are first identified using related literature studies and then, the list of risks is completed or revised using expert views, assessment criteria for prioritization of risks are calculated, and finally, the risk level for each candidate private company is determined.

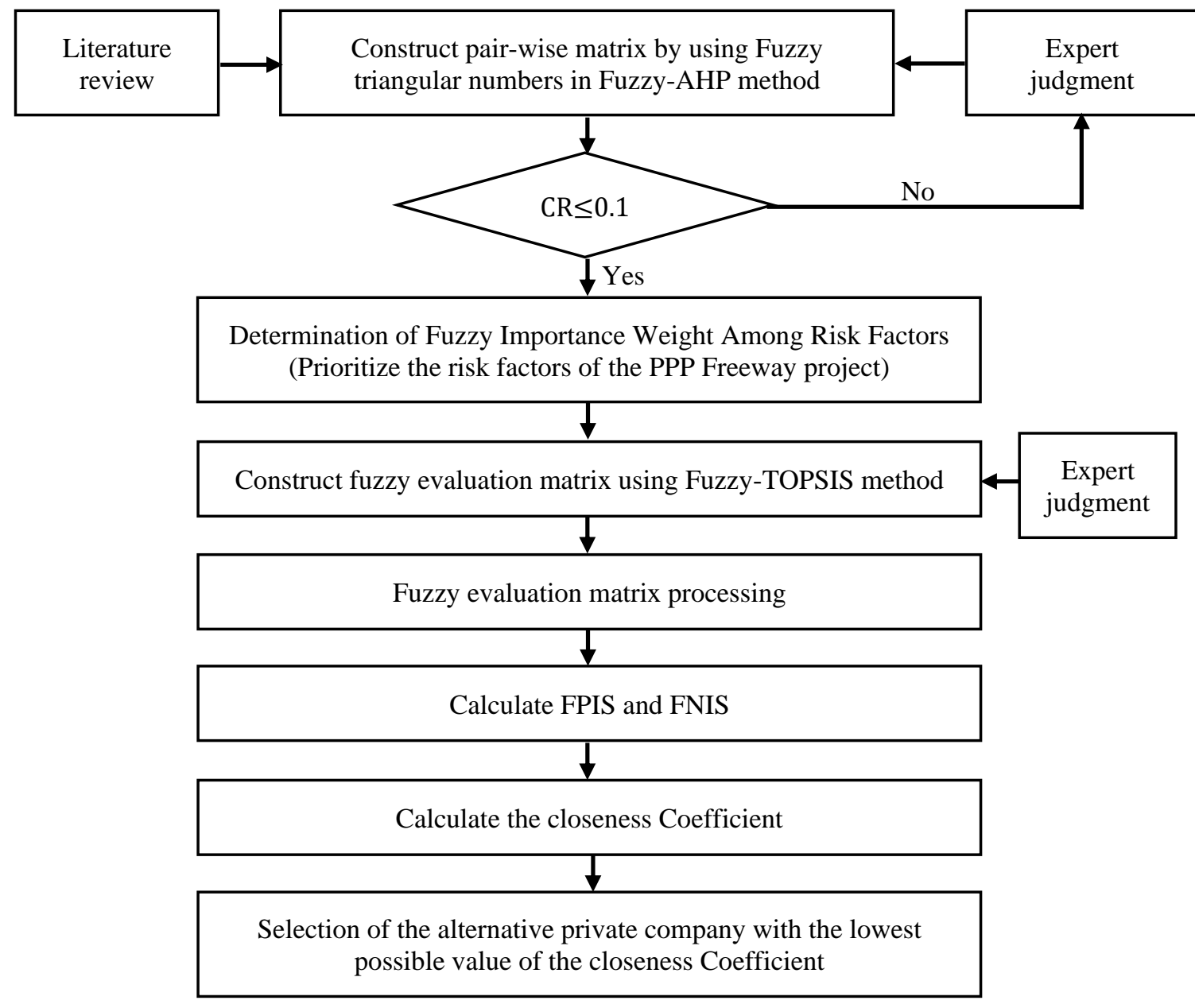

Fig. 1. The proposed methodology for the freeway project's risk prioritization and selection of the contactor private company 
Table 2. Information about experts filling out the questionnaires

\begin{tabular}{lcc}
\hline $\begin{array}{l}\text { Experts' field of } \\
\text { activity }\end{array}$ & Number & Percentage \\
\hline $\begin{array}{l}\text { Academic } \\
\text { Ministry of roads and }\end{array}$ & 8 & 26.66 \\
$\begin{array}{l}\text { urban development } \\
\text { Private companies } \\
\text { for the development } \\
\text { of freeways }\end{array}$ & 7 & 23.44 \\
\hline
\end{tabular}

In addition, in the proposed method, assessment risk criteria are expressed using verbal variables such as very high, high, average, low, etc. These values are converted into numerical ones using fuzzy logic theory and triangular membership functions. After prioritizing project risks using hybrid fuzzy AHP, the company which has the lowest risk result from fuzzy TOPSIS will be selected as the executor company for SavehSalafchegan freeway PPP project. Based on risk factors identified using literature review and expert views and also results of simulations performed in the present study, the following suggestions can be made to ensure the project is executed successfully. Therefore, based on risk factors provided in the present study, these suggestions can be applied to the technical, basic, political, economic, environmental and social risks of the project. In the following sections, first of all, basic principles of fuzzy logic and fuzzy numbers are reviewed and then, fuzzy TOPSIS and fuzzy AHP methods are introduced.

\subsection{Fuzzy AHP}

One of the problems that AHP is faced with is its inability to manage uncertainties under real conditions and lack of precision in pairwise comparisons. To overcome this problem, [20] has proposed a fuzzy AHP approach based on extent analysis which is widely used in selecting the right alternative for the execution of projects. This approach makes use of verbal variables to express comparative judgments of project experts. The relative importance (interdependence) of problem's criteria and sub-criteria is measured on a scale of 1 to 9 and the meaning of each number is explained in Table 3 where $A=\left[a_{i j}\right]_{n \times n}$ is the pairwise comparisons matrix.

First, suppose that $X=\left\{x_{1}, x_{2}, \ldots, x_{n}\right\}$ is a set of criteria and $G=\left\{g_{1}, g_{2}, \ldots, g_{n}\right\}$ is a set of problem goals. In the fuzzy method, for each $\mathrm{x}_{\mathrm{i}}$ criteria on each $g_{j}$ goal, values of extent analysis are calculated as $M_{g_{i}}^{1}, \ldots, M_{g_{i}}^{m}$ for $i=1,2, \ldots, n$ in which all $M_{g_{i}}^{j}$ are triangular fuzzy numbers. The steps of this approach can be described as follows:

Step 1: Create a hierarchy.

Step 2: Define fuzzy numbers for pairwise comparisons. For determining the importance and priority of criteria and sub-criteria, fuzzy numbers have to be given in the questionnaire for pairwise comparisons. The fuzzy numbers are shown in Table 3.

Step 3: Create a pairwise matrix using fuzzy numbers.

Step 4: First, the results of the fuzzy extent analysis for the $\mathrm{i}^{\text {th }}$ criteria are calculated based on Eq. 1:

$S_{i}=\sum_{j=1}^{m} M_{g_{i}}^{j} \otimes\left[\sum_{i=1}^{n} \sum_{j=1}^{m} M_{g_{i}}^{j}\right]^{-1}$

and the value for $\sum_{j=1}^{m} M_{g_{i}}^{j}$ is calculated using fuzzy addition operator on $m$ in fuzzy extent analysis as follows:

$\sum_{j=1}^{m} M_{g_{i}}^{j}=\left(\sum_{j=1}^{m} l_{j}, \sum_{j=1}^{m} m_{j}, \sum_{j=1}^{m} u_{j}\right)$

Table 3. Meanings of matrix entries for the pairwise comparisons in normal AHP [28]

\begin{tabular}{ll}
\hline Value & Meaning \\
\hline 1 & $\begin{array}{l}\text { The criteria } \mathrm{i} \text { and } \mathrm{j} \text { have the } \\
\text { same importance. } \\
3\end{array}$ \\
$\mathrm{i}$ is less important than $\mathrm{j}$. \\
Based on expert views, $\mathrm{i}$ is \\
much more important than $\mathrm{j}$. \\
7 & $\begin{array}{l}\mathrm{i} \text { is significantly more } \\
\text { important than } \mathrm{j} .\end{array}$ \\
9 & $\begin{array}{l}\mathrm{i} \text { is definitely more important } \\
\text { than } \mathrm{j} .\end{array}$ \\
$2,4,6,8$ & Average values \\
\hline
\end{tabular}


Also, the value of $\left[\sum_{i=1}^{n} \sum_{j=1}^{m} M_{g_{i}}^{j}\right]^{-1}$ is calculated using Eq. 3:

$\left[\sum_{i=1}^{n} \sum_{j=1}^{m} M_{g_{i}}^{j}\right]^{-1}=$

$\left(\frac{1}{\sum_{i=1}^{n} \sum_{j=1}^{m} u_{i}}, \frac{1}{\sum_{i=1}^{n} \sum_{j=1}^{m} m_{i}}, \frac{1}{\sum_{i=1}^{n} \sum_{j=1}^{m} l_{i}}\right)$

Step 5: In this step, the possibility of $\boldsymbol{S}_{\mathbf{2}}\left(l_{2}, m_{2}, u_{2}\right) \geq \boldsymbol{S}_{\mathbf{1}}\left(l_{1}, m_{1}, u_{1}\right)$, where $\mathrm{S}_{1}$ and $\mathrm{S}_{2}$ are from Eq. 1, is calculated. The value calculated between Fuzzy extents are defined as follows:

$V\left(S_{2} \geq S_{1}\right)=\sup _{y \geq x}\left[\min \left(\mu_{S_{2}}(y), \mu_{S_{1}}(x)\right)\right]=$

$\left\{\begin{array}{c}1 ; \text { if } m_{2} \geq m_{1} \\ 0 ; \text { if } l_{1} \geq u_{2} \\ \frac{l_{1}-u_{2}}{\left(m_{2}-u_{2}\right)-\left(m_{1}-l_{1}\right)} ; \text { otherwise }\end{array}\right.$

Step 6: Determine the possibility of a convex fuzzy number between $k$ numbers of $\mathrm{S}_{\mathrm{i}}$ ( $i=$ $1, \ldots, k)$. This possibility is calculated using Eq. 5:

$V\left(S \geq S_{1}, S_{2}, \ldots, S_{k}\right)=V\left[\left(S \geq S_{1}\right) \operatorname{and}(S \geq\right.$ $S_{1}$ ) and $\ldots$ and $\left.\left.S \geq S_{k}\right)\right]=\min _{1 \leq i \leq k} V\left(S \geq S_{i}\right)$

Step 7: The vector $W^{\prime}$ is calculated as follows:

$W^{\prime}=\left(d^{\prime}\left(A_{1}\right), d^{\prime}\left(A_{2}\right), \ldots, d^{\prime}\left(A_{k}\right)\right)^{T}$

Supposing that $d^{\prime}\left(A_{i}\right)=\min \left(V\left(S_{i} \geq S_{j}\right)\right)$ is true for $i=1, \ldots, k$ and $j=1, \ldots, k(i \neq j)$, the normalized vector will be calculated as follows:
$\mathrm{W}=\frac{\left(d^{\prime}\left(A_{1}\right), d^{\prime}\left(A_{2}\right), \ldots, d^{\prime}\left(A_{k}\right)\right)^{T}}{\sum_{l=1}^{k} d^{\prime}\left(A_{l}\right)}$

where $W$ is a non-Fuzzy number calculated for each pairwise comparisons. In this method, the fuzzy conversion scale based on triangular Fuzzy numbers $(l, m, u)$ is shown in Table 4 . In fact, Table 4 contains the Fuzzy equivalents of values in the pairwise comparisons matrix presented in Table 3.

\subsection{Risk assessment using Fuzzy TOPSIS}

In this section, an integrated Fuzzy TOPSIS method is presented. Suppose that $m$ is the candidate selected for executing the project $\mathrm{A}_{\mathrm{i}}$ ( $i=$ $1,2, \ldots, m)$ with a risk criterion of $\mathrm{n}(j=1,2, \ldots, n)$. Initial assessment values will be shown with $\tilde{x}_{i j}$ and $p$ experts have been used for assessing the qualitative criteria of each project candidate. First of all, initial assessment values $\left(\tilde{x}_{i j}\right)$ should be determined using questionnaires and after that, the Fuzzy evaluation matrix has to be determined. Using expert views, the Fuzzy judgment matrix for each candidate of the PPP project is determined using verbal variables. The following steps show how the overall risk level of each candidate company for executing Saveh-Salafchegan Freeway PPP Project is calculated using Fuzzy TOPSIS method:

Table 4 Interpretation of paired comparisons matrix elements in fuzzy AHP method

\begin{tabular}{|c|c|c|}
\hline Interpretation of scales & Triangular Fuzzy scales & Inverse triangular Fuzzy scales \\
\hline $\begin{array}{l}\text { The criteria } i \text { and } j \\
\text { have the same } \\
\text { importance. }\end{array}$ & $(1,1,1)$ & $(1,1,1)$ \\
\hline $\begin{array}{l}i \text { is less important than } \\
j \text {. }\end{array}$ & $\left(\frac{2}{3}, 1, \frac{3}{2}\right)$ & $\left(\frac{2}{3}, 1, \frac{3}{2}\right)$ \\
\hline $\begin{array}{l}\text { Based on expert } \\
\text { views, } i \text { is much more } \\
\text { important than } j .\end{array}$ & $\left(\frac{3}{2}, 2, \frac{5}{2}\right)$ & $\left(\frac{2}{5}, \frac{1}{2}, \frac{2}{3}\right)$ \\
\hline $\begin{array}{l}i \text { is significantly more } \\
\text { important than } j \text {. }\end{array}$ & $\left(\frac{5}{2}, 3, \frac{7}{2}\right)$ & $\left(\frac{2}{7}, \frac{1}{3}, \frac{7}{2}\right)$ \\
\hline $\begin{array}{l}i \text { is definitely more } \\
\text { important than } j \text {. }\end{array}$ & $\left(\frac{7}{2}, 4, \frac{9}{2}\right)$ & $\left(\frac{2}{9}, \frac{1}{4}, \frac{2}{2}\right)$ \\
\hline Average values & $\begin{array}{c}\left(2, \frac{5}{2}, 3\right) \cdot\left(1, \frac{3}{2}, 2\right) \cdot\left(\frac{1}{2}, \frac{3}{4}, 1\right) \\
\left(3, \frac{7}{2}, 4\right) \text { and }\end{array}$ & $\begin{array}{c}\text { and }\left(\frac{1}{3}, \frac{2}{5}, \frac{1}{2}\right) \cdot\left(\frac{1}{2}, \frac{2}{3}, 1\right) \cdot\left(1, \frac{4}{3}, 2\right) \\
\left(\frac{1}{4}, \frac{2}{7}, \frac{1}{3}\right)\end{array}$ \\
\hline
\end{tabular}


Step 1: First, verbal judgments of experts such as "high" or "very low" should be converted into Fuzzy numbers with a Fuzzy triangular membership function $\mu_{A}(x)$ which is defined using three parameters $(a, b, c)$. The form and relationships of this function can be shown as illustrated in Fig. 2 and Eq. 8. In addition, verbal variables can be shown as their equivalent Fuzzy numbers using the rules given in Table 5 .

$\mu_{A}(x ; a, b, c)=\left\{\begin{array}{l}0 ; x \leq a \text { or } x \geq c \\ \frac{x-a}{b-a} ; a \leq x \leq b \\ \frac{c-x}{c-b} ; b \leq x \leq c\end{array}\right.$

Step 2: Using expert views and judgments, create the Fuzzy evaluation matrix. First, process the $j^{\text {th }}$ criteria related to the $\mathrm{i}^{\text {th }}$ candidate from the $\mathrm{s}^{\text {th }}$ expert view using Eq. 9 in order to calculate the assessment of the $\mathrm{j}^{\text {th }}$ criteria related to the $\mathrm{i}^{\text {th }}$ candidate. Next, create the Fuzzy evaluation matrix as shown in Eq. 10.

$f_{i j}=\left(a_{i j}, b_{i j}, c_{i j}\right)=\lambda_{1} x_{i j}^{1} \oplus \lambda_{2} x_{i j}^{2} \oplus \ldots \oplus$

$\lambda_{p} x_{i j}^{p}=\left(\left(1-\prod_{s=1}^{p}(1-\right.\right.$

$\left.\left.\left.u_{i j}^{s}\right)^{\lambda_{s}}\right), \prod_{s=1}^{p}\left(v_{i j}^{s}\right)^{\lambda_{s}}, \prod_{s=1}^{p}\left(\pi_{i j}^{s}\right)^{\lambda_{s}}\right)$

$\widetilde{D}=\begin{gathered}A_{1} \\ A_{2} \\ \left.\begin{array}{ccccc}\tilde{x}_{11} & \tilde{x}_{12} & u_{2} & \ldots & u_{n} \\ \tilde{x}_{21} & \tilde{x}_{22} & \ldots & \tilde{x}_{2 n} \\ A_{m} & \vdots & \vdots & \vdots & \vdots \\ \tilde{x}_{m 1} & \tilde{x}_{m 2} & \ldots & \tilde{x}_{m n}\end{array}\right]\end{gathered}$

where $\widetilde{D}=\left[\tilde{x}_{i j}\right]_{m \times n}$ is the initial value of the criteria $\mathrm{u}_{\mathrm{j}}$ for the candidate $\mathrm{A}_{\mathrm{i}}$.

Step 3: In this step, the Fuzzy evaluation matrix has to be normalized using Eq. 11.

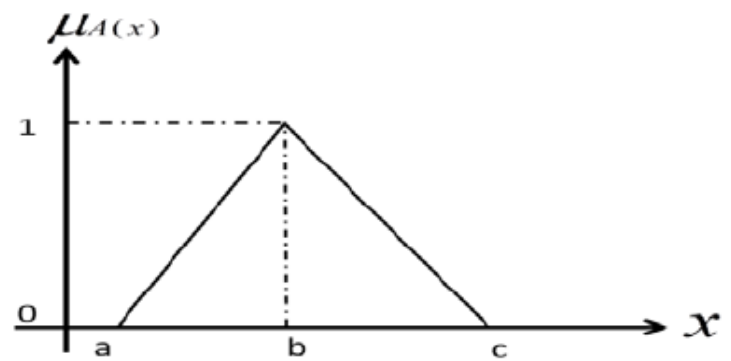

Fig. 2. The triangular membership function $\mu_{A}(x)$
$\tilde{R}=\left[\tilde{r}_{i j}\right]_{m \times n} ; i=1,2, \ldots, m ; j=1,2, \ldots, n$

In addition, if $c_{j}^{+}$is the benefit criteria and $c_{j}^{+}=$ $\max _{i}\left(c_{i j}\right)$, we will have: $\tilde{r}_{i j}=\left(\frac{a_{i j}}{c_{j}^{+}}, \frac{b_{i j}}{c_{j}^{+}}, \frac{c_{i j}}{c_{j}^{+}}\right)$; also, if $a_{j}^{+}$is the benefit criteria and $a_{j}^{+}=\min _{i}\left(a_{i j}\right)$, we will have: $\tilde{r}_{i j}=\left(\frac{a_{j}^{+}}{a_{i j}}, \frac{a_{j}^{+}}{b_{i j}}, \frac{a_{j}^{+}}{c_{i j}}\right)$.

Step 4: Determine the weighted normalized Fuzzy evaluation matrix:

$Z=\left[\tilde{z}_{i j}\right]_{m \times n}, i=1,2, \ldots, m ; j=1,2, \ldots, n$

where $\tilde{z}_{i j}=\tilde{r}_{i j} \times w_{j} ; i=1,2, \ldots, m, j=1,2, \ldots, n$.

Step 5: Determine the Fuzzy positive ideal solution (FPIS) and the Fuzzy negative ideal solution (FNIS).

$\boldsymbol{Q}^{-}=\left(\tilde{z}_{1}^{-}, \tilde{z}_{2}^{-}, \ldots, \tilde{z}_{n}^{-}\right), \boldsymbol{Q}^{+}=\left(\tilde{z}_{1}^{+}, \tilde{z}_{2}^{+}, \ldots, \tilde{z}_{n}^{+}\right)$

where $\quad \tilde{z}_{j}^{-}=\min _{i}\left(z_{i j}\right), \tilde{z}_{j}^{+}=\max _{i}\left(z_{i j}\right) ; i=$ $1,2, \ldots, m, j=1,2, \ldots, n$.

Step 6: Calculate the $d_{i}^{-}$and $d_{i}^{+}$difference between each FPIS and FNIS candidates using Eqs. 14 and 15 , respectively.

$d_{i}^{-}=\sum_{j=1}^{n} d\left(z_{i j}, \tilde{z}_{j}^{-}\right), i=1,2, \ldots, m ; j=$

$1,2, \ldots, n$

$d_{i}^{+}=\sum_{j=1}^{n} d\left(z_{i j}, \tilde{z}_{j}^{+}\right), i=1,2, \ldots, m ; j=1,2, \ldots, n$

where

$$
d(\widetilde{\boldsymbol{a}}, \tilde{\mathbf{b}})=\sqrt{\frac{1}{3} \sum_{i=1}^{3}\left(a_{i}-b_{i}\right)^{2}} \text { is the }
$$

difference between two Fuzzy triangular numbers $\widetilde{\boldsymbol{a}}$ and $\widetilde{\boldsymbol{b}}$.

Step 7: Calculate the closeness coefficient of the $i^{\text {th }}$ private company using Eq. 16 and order the values in descending order:

$C C_{i}=\frac{d_{i}^{-}}{d_{i}^{+}+d_{i}^{-}}, i=1,2, \ldots, m$

If the closeness coefficient is close to 1 , the candidate will have the best performance but since the goal of the study is to find the company with the lowest overall risk level, the private company with the lowest closeness coefficient is selected as the fittest candidate. 
Table 5 Significance of risk factors in Fuzzy AHP expressed using triangular Fuzzy scale

\begin{tabular}{ccccc}
\hline Main criteria & $\begin{array}{c}\text { Basic and political } \\
\text { risks }\end{array}$ & Economic risks & $\begin{array}{c}\text { Environmental and } \\
\text { social risks }\end{array}$ & Technical risks \\
\hline $\begin{array}{c}\text { Basic and political } \\
\text { risks }\end{array}$ & $(1,1,1)$ & $\left(\frac{1}{2}, \frac{3}{4}, 1\right)$ & $\left(\frac{3}{2}, 2, \frac{5}{2}\right)$ & $\left(\frac{5}{2}, 3, \frac{7}{2}\right)$ \\
Economic risks & $\left(1, \frac{4}{3}, 2\right)$ & $(1,1,1)$ & $\left(\frac{2}{3}, 1, \frac{3}{2}\right)$ & $\left(\frac{2}{3}, 1, \frac{3}{2}\right)$ \\
$\begin{array}{c}\text { Environmental and } \\
\text { social risks }\end{array}$ & $\left(\frac{2}{5}, \frac{1}{2}, \frac{2}{3}\right)$ & $\left(\frac{2}{3}, 1, \frac{3}{2}\right)$ & $(1,1,1)$ & $\left(\frac{2}{7}, \frac{1}{3}, \frac{2}{5}\right)$ \\
Technical risks & $\left(\frac{2}{3}, 1, \frac{3}{2}\right)$ & $\left(\frac{2}{3}, 1, \frac{3}{2}\right)$ & $\left(\frac{5}{2}, 3, \frac{7}{2}\right)$ & $(1,1,1)$ \\
\hline
\end{tabular}

\subsection{Identifying risk factors using expert views}

Identifying risk factors is of crucial importance to project risk control and successful project implementation [21]. To identify risk factors and select effective assessment criteria, as mentioned earlier, a two-step questionnaire is used for gathering data which is a popular method for analyzing the risk of PPP projects. First, the list shown in Table 1 is updated using expert views as suggested in Table 2. As can be seen, risk factors of increased tolls of the freeway, increased costs of building the freeway, and increased time period for finishing the freeway are added to the final 24-item list suggested by project experts, and also, some insignificant factors have been removed.

\subsection{Applying the proposed method to the case study (Saveh-Salafchegan Freeway)}

In the present study, Saveh-Salafchegan's freeway has been selected as the case study and MCDM has been used to select the company for implementing the project from among three available candidates A1, A2, and A3. Considering the plan to create a direct freeway route from Tehran to Imam Khomeini Port in the south of Iran and also the existence of several connecting freeways between Tehran and other provinces, implementation of Saveh-Salafchegan Freeway is of great importance. This freeway, in the center of Iran near Saveh and Qom, is 68 kilometers long and connects several freeways to one another. This project started in 1380 and finished in 1383. One side of the freeway was completed by the Ministry of Roads and Urban
Development and $80 \%$ of the other side was completed by a private company named "Shaloudeh" (Persian for "foundation"). To prioritize the risk factor of the Saveh-Salafchegan freeway PPP Project, first, we will make use of fuzzy AHP. Tables 5 to 9 show expert views on the risk factors of this project. By processing these tables using fuzzy AHP, the weight for each risk factor proposed in the present study will be determined. Table 10 shows the local and general weights of sub-criteria and also weights of the main risk factor that are obtained by fuzzy AHP.

Also, to help the private sector make the right decision, the risk levels of all candidate companies will be analyzed and prioritized using the proposed methodology. Therefore, we have invited several experts for interviews to determine the Fuzzy evaluation matrix and initial data. These experts include an officer E1 from the Iranian center of public and private partnerships, a project manager E2 from a company for development of freeways, a university professor E3 who has a lot of management experience in freeway development, and a college student E4 who uses this freeway regularly for commuting to and from university. Weights of experts are considered as $\lambda=(0.27,0.25,0.25,0.23)$. The following steps show how Fuzzy TOPSIS is used for risk assessment of a freeway PPP project:

Step 1:Verbal judgments of our four PPP project experts are converted into Fuzzy numbers. The Fuzzy evaluation matrix using verbal judgments and views of experts E1, E2, E3, and E4. The results are illustrated in Table 11. 
Table 6. Significance of basic and political risks factors in Fuzzy AHP

\begin{tabular}{lcccc}
\hline Criteria & Politics & $\begin{array}{l}\text { Government } \\
\text { interference }\end{array}$ & Government funding & Corruption \\
\hline Politics & $(1,1,1)$ & $(1,1,1)$ & $\left(\frac{3}{2}, 2, \frac{5}{2}\right)$ & $\left(\frac{2}{3}, 1, \frac{3}{2}\right)$ \\
$\begin{array}{l}\text { Government } \\
\text { interference }\end{array}$ & $(1,1,1)$ & $(1,1,1)$ & $\left(\frac{2}{3}, 1, \frac{3}{2}\right)$ & $\left(\frac{3}{2}, 2, \frac{5}{2}\right)$ \\
Government funding & $\left(\frac{2}{5}, \frac{1}{2}, \frac{2}{3}\right)$ & $\left(\frac{2}{3}, 1, \frac{3}{2}\right)$ & $(1,1,1)$ & $\left(\frac{1}{2}, \frac{3}{4}, 1\right)$ \\
Corruption & $\left(\frac{2}{3}, 1, \frac{3}{2}\right)$ & $\left(\frac{2}{5}, \frac{1}{2}, \frac{2}{3}\right)$ & $\left(1, \frac{4}{3}, 2\right)$ & $(1,1,1)$ \\
\hline
\end{tabular}

Table 7. Significance of economic risk factors in Fuzzy AHP

\begin{tabular}{lcccc}
\hline Main criteria & Market & Interest rate fluctuations & Income & Payment \\
\hline Market & $(1,1,1)$ & $\left(\frac{1}{2}, \frac{3}{4}, 1\right)$ & $\left(\frac{3}{2}, 2, \frac{5}{2}\right)$ & $\left(\frac{3}{2}, 2, \frac{5}{2}\right)$ \\
Interest rate fluctuations & $\left(1, \frac{4}{3}, 2\right)$ & $(1,1,1)$ & $\left(\frac{2}{3}, 1, \frac{3}{2}\right)$ & $\left(2, \frac{5}{2}, 3\right)$ \\
Income & $\left(\frac{2}{5}, \frac{1}{2}, \frac{2}{3}\right)$ & $\left(\frac{2}{3}, 1, \frac{3}{2}\right)$ & $(1,1,1)$ & $\left(\frac{2}{3}, 1, \frac{3}{2}\right)$ \\
Payment & $\left(\frac{2}{5}, \frac{1}{2}, \frac{2}{3}\right)$ & $\left(\frac{1}{3}, \frac{2}{5}, \frac{1}{2}\right)$ & $\left(\frac{2}{3}, 1, \frac{3}{2}\right)$ & $(1,1,1)$ \\
\hline
\end{tabular}

Table 8. Significance of environmental and social risk factors in Fuzzy AHP

\begin{tabular}{lcc}
\hline Main criteria & Increased freeway tolls & Lack of supporting equipment \\
\hline Increased freeway tolls & $(1,1,1)$ & $(1,1,1)$ \\
Lack of supporting equipment & $(1,1,1)$ & $(1,1,1)$ \\
\hline
\end{tabular}

Table 9. Significance of technical risk factors of the project in Fuzzy AHP

\begin{tabular}{|c|c|c|c|c|c|c|c|}
\hline Criteria & Performance & $\begin{array}{l}\text { Increased costs of } \\
\text { implementation }\end{array}$ & $\begin{array}{l}\text { Increased } \\
\text { project } \\
\text { duration }\end{array}$ & Implementation & $\begin{array}{c}\text { Lack of } \\
\text { experience } \\
\text { with PPP } \\
\text { projects }\end{array}$ & $\begin{array}{l}\text { Project } \\
\text { uniqueness }\end{array}$ & $\begin{array}{l}\text { Operational } \\
\text { risks }\end{array}$ \\
\hline Performance & $\left(\frac{3}{2}, 2, \frac{5}{2}\right)$ & $\left(\frac{5}{2}, 3, \frac{7}{2}\right)$ & $\left(\frac{5}{2}, 3, \frac{7}{2}\right)$ & $\left(\frac{2}{3}, 1, \frac{3}{2}\right)$ & $\left(\frac{2}{3}, 1, \frac{3}{2}\right)$ & $\left(\frac{1}{2}, \frac{3}{4}, 1\right)$ & $(1,1,1)$ \\
\hline $\begin{array}{l}\text { Increased costs of } \\
\text { implementation }\end{array}$ & $\left(\frac{3}{2}, 2, \frac{5}{2}\right)$ & $\left(\frac{5}{2}, 3, \frac{7}{2}\right)$ & $\left(1, \frac{3}{2}, 2\right)$ & $\left(\frac{2}{3}, 1, \frac{3}{2}\right)$ & $\left(\frac{2}{3}, 1, \frac{3}{2}\right)$ & $(1,1,1)$ & $\left(1, \frac{4}{3}, 2\right)$ \\
\hline $\begin{array}{l}\text { Increased project } \\
\text { duration }\end{array}$ & $\left(1, \frac{3}{2}, 2\right)$ & $\left(\frac{3}{2}, 2, \frac{5}{2}\right)$ & $\left(\frac{2}{3}, 1, \frac{3}{2}\right)$ & $\left(\frac{1}{2}, \frac{3}{4}, 1\right)$ & $(1,1,1)$ & $\left(\frac{2}{3}, 1, \frac{3}{2}\right)$ & $\left(\frac{2}{3}, 1, \frac{3}{2}\right)$ \\
\hline Implementation & $\left(2, \frac{5}{2}, 3\right)$ & $\left(\frac{5}{2}, 3, \frac{7}{2}\right)$ & $\left(\frac{1}{2}, \frac{3}{4}, 1\right)$ & $(1,1,1)$ & $\left(1, \frac{4}{3}, 2\right)$ & $\left(\frac{2}{3}, 1, \frac{3}{2}\right)$ & $\left(\frac{2}{3}, 1, \frac{3}{2}\right)$ \\
\hline $\begin{array}{l}\text { Lack of experience } \\
\text { with PPP projects }\end{array}$ & $\left(\frac{3}{2}, 2, \frac{5}{2}\right)$ & $\left(\frac{2}{3}, 1, \frac{3}{2}\right)$ & $(1,1,1)$ & $\left(1, \frac{4}{3}, 2\right)$ & $\left(\frac{2}{3}, 1, \frac{3}{2}\right)$ & $\left(\frac{1}{2}, \frac{2}{3}, 1\right)$ & $\left(\frac{2}{7}, \frac{1}{3}, \frac{2}{5}\right)$ \\
\hline Project uniqueness & $\left(\frac{2}{3}, 1, \frac{3}{2}\right)$ & $(1,1,1)$ & $\left(\frac{2}{3}, 1, \frac{3}{2}\right)$ & $\left(\frac{2}{7}, \frac{1}{3}, \frac{2}{5}\right)$ & $\left(\frac{2}{5}, \frac{1}{2}, \frac{2}{3}\right)$ & $\left(\frac{2}{7}, \frac{1}{3}, \frac{2}{5}\right)$ & $\left(\frac{2}{7}, \frac{1}{3}, \frac{2}{5}\right)$ \\
\hline Operational risks & $(1,1,1)$ & $\left(\frac{2}{3}, 1, \frac{3}{2}\right)$ & $\left(\frac{2}{5}, \frac{1}{2}, \frac{2}{3}\right)$ & $\left(\frac{1}{3}, \frac{2}{5}, \frac{1}{2}\right)$ & $\left(\frac{1}{2}, \frac{2}{3}, 1\right)$ & $\left(\frac{2}{5}, \frac{1}{2}, \frac{2}{3}\right)$ & $\left(\frac{2}{5}, \frac{1}{2}, \frac{2}{3}\right)$ \\
\hline
\end{tabular}


Table 10. Weights of main risk factors and the list of identified risks allocated using literature review and expert views

\begin{tabular}{|c|c|c|c|c|}
\hline $\begin{array}{l}\text { Main risk } \\
\text { (criteria) }\end{array}$ & Risk factors & $\begin{array}{l}\text { Local weight of } \\
\text { sub-criteria }\end{array}$ & $\begin{array}{l}\text { Criteria } \\
\text { weight }\end{array}$ & $\begin{array}{l}\text { The general weight of } \\
\text { sub-criteria }\end{array}$ \\
\hline \multirow{5}{*}{$\begin{array}{l}\text { Basic and } \\
\text { political risks }\end{array}$} & Politics & 0.3105 & & 0.0886 \\
\hline & $\begin{array}{l}\text { Government } \\
\text { interference }\end{array}$ & 0.3105 & & 0.0886 \\
\hline & $\begin{array}{l}\text { Government } \\
\text { funding }\end{array}$ & 0.1557 & & 0.0444 \\
\hline & Corruption & 0.2233 & & 0.0637 \\
\hline & $\begin{array}{l}\text { Basic and } \\
\text { political risks }\end{array}$ & - & 0.2853 & \\
\hline \multirow{5}{*}{ Economic risks } & Market & 0.3631 & & 0.0957 \\
\hline & $\begin{array}{l}\text { Interest rate } \\
\text { fluctuations }\end{array}$ & 0.3690 & & 0.0973 \\
\hline & Income & 0.1788 & & 0.0471 \\
\hline & Payment & 0.0892 & & 0.0235 \\
\hline & Economic risks & & 0.2636 & \\
\hline \multirow{3}{*}{$\begin{array}{l}\text { Environmental } \\
\text { and social risks }\end{array}$} & $\begin{array}{l}\text { Increased freeway } \\
\text { tolls }\end{array}$ & 0.5 & & 0.0362 \\
\hline & $\begin{array}{l}\text { Lack of } \\
\text { supporting } \\
\text { equipment }\end{array}$ & 0.5 & & 0.0362 \\
\hline & $\begin{array}{l}\text { Environmental } \\
\text { and social risks }\end{array}$ & & 0.0725 & \\
\hline \multirow{8}{*}{ Technical risks } & Performance & 0.2410 & & 0.0912 \\
\hline & $\begin{array}{l}\text { Increased costs of } \\
\text { implementation }\end{array}$ & 0.2221 & & 0.0841 \\
\hline & $\begin{array}{l}\text { Increased project } \\
\text { duration }\end{array}$ & 0.1602 & & 0.0607 \\
\hline & Implementation & 0.2162 & & 0.0819 \\
\hline & $\begin{array}{l}\text { Lack of } \\
\text { experience with } \\
\text { PPP projects }\end{array}$ & 0.1340 & & 0.0507 \\
\hline & $\begin{array}{l}\text { Project } \\
\text { uniqueness }\end{array}$ & 0.0107 & & 0.0041 \\
\hline & Operational risks & 0.0159 & & 0.006 \\
\hline & Technical risks & & 0.3786 & \\
\hline
\end{tabular}


Table 11. Creating the Fuzzy evaluation matrix using verbal judgments and views of experts E1, E2, E3, and E4

\begin{tabular}{|c|c|c|c|c|c|c|c|c|c|c|c|c|c|}
\hline \multirow{2}{*}{$\begin{array}{l}\text { Main risk } \\
\text { (criteria) }\end{array}$} & \multirow{2}{*}{ Risk factors } & \multicolumn{4}{|c|}{ Candidate $\mathrm{A}_{1}$} & \multicolumn{4}{|c|}{ Candidate $\mathrm{A}_{2}$} & \multicolumn{4}{|c|}{ Candidate $\mathrm{A}_{3}$} \\
\hline & & E1 & E2 & E3 & $\mathrm{E} 4$ & E1 & $\mathrm{E} 2$ & E3 & $\mathrm{E} 4$ & E1 & E2 & E3 & E4 \\
\hline \multirow{4}{*}{$\begin{array}{l}\text { Basic and } \\
\text { political risks }\end{array}$} & Politics & $\mathrm{H}$ & $\mathrm{M}$ & $\mathrm{H}$ & $\mathrm{H}$ & $\mathrm{VH}$ & $\mathrm{M}$ & VH & $\mathrm{H}$ & VH & VH & $\mathrm{H}$ & $\mathrm{H}$ \\
\hline & $\begin{array}{l}\text { Government } \\
\text { interference }\end{array}$ & $\mathrm{H}$ & VH & $\mathrm{VH}$ & $\mathrm{H}$ & $\mathrm{VH}$ & M & VH & VH & $\mathrm{H}$ & VH & $\mathrm{H}$ & $\mathrm{H}$ \\
\hline & $\begin{array}{l}\text { Government } \\
\text { funding }\end{array}$ & VH & VH & $\mathrm{H}$ & $\mathrm{VH}$ & $\mathrm{L}$ & $\mathrm{H}$ & VH & $\mathrm{H}$ & $\mathrm{M}$ & $\mathrm{H}$ & $\mathrm{H}$ & $\mathrm{VH}$ \\
\hline & Corruption & $\mathrm{H}$ & $\mathrm{H}$ & $\mathrm{VH}$ & $\mathrm{H}$ & $\mathrm{L}$ & VH & VH & VH & M & $\mathrm{H}$ & M & $\mathrm{H}$ \\
\hline \multirow{4}{*}{$\begin{array}{l}\text { Economic } \\
\text { risks }\end{array}$} & Market & $\mathrm{M}$ & $\mathrm{H}$ & $\mathrm{M}$ & VH & M & VH & $\mathrm{H}$ & $\mathrm{H}$ & M & $\mathrm{M}$ & $\mathrm{H}$ & $\mathrm{H}$ \\
\hline & $\begin{array}{l}\text { Interest rate } \\
\text { fluctuations }\end{array}$ & $\mathrm{VH}$ & $\mathrm{VH}$ & $\mathrm{H}$ & $\mathrm{H}$ & M & $\mathrm{H}$ & $\mathrm{H}$ & $\mathrm{H}$ & M & $\mathrm{VH}$ & $\mathrm{H}$ & $\mathrm{H}$ \\
\hline & Income & $\mathrm{M}$ & $\mathrm{L}$ & M & $\mathrm{H}$ & $\mathrm{M}$ & $\mathrm{L}$ & $\mathrm{M}$ & M & $\mathrm{M}$ & M & $\mathrm{M}$ & $\mathrm{M}$ \\
\hline & Payment & $\mathrm{H}$ & M & M & M & $\mathrm{M}$ & $\mathrm{L}$ & $\mathrm{M}$ & M & $\mathrm{L}$ & M & $\mathrm{L}$ & $\mathrm{M}$ \\
\hline \multirow{2}{*}{$\begin{array}{l}\text { Environmental } \\
\text { and social } \\
\text { risks }\end{array}$} & $\begin{array}{l}\text { Increased } \\
\text { freeway tolls }\end{array}$ & $\mathrm{H}$ & $\mathrm{H}$ & $\mathrm{H}$ & $\mathrm{VH}$ & $\mathrm{L}$ & VH & M & $\mathrm{VH}$ & $\mathrm{H}$ & VH & M & $\mathrm{VH}$ \\
\hline & $\begin{array}{l}\text { Lack of } \\
\text { supporting } \\
\text { equipment }\end{array}$ & $\mathrm{H}$ & VH & $\mathrm{H}$ & M & $\mathrm{H}$ & VH & M & $\mathrm{VH}$ & $\mathrm{H}$ & $\mathrm{M}$ & VH & $\mathrm{VH}$ \\
\hline \multirow{7}{*}{$\begin{array}{l}\text { Technical } \\
\text { risks }\end{array}$} & Performance & $\mathrm{M}$ & $\mathrm{H}$ & $\mathrm{M}$ & $\mathrm{H}$ & $\mathrm{H}$ & $\mathrm{H}$ & $\mathrm{H}$ & $\mathrm{H}$ & M & $\mathrm{H}$ & $\mathrm{H}$ & $\mathrm{VH}$ \\
\hline & $\begin{array}{l}\text { Increased costs } \\
\text { of } \\
\text { implementation }\end{array}$ & $\mathrm{H}$ & $\mathrm{H}$ & $\mathrm{H}$ & $\mathrm{H}$ & $\mathrm{VH}$ & $\mathrm{VH}$ & $\mathrm{H}$ & $\mathrm{VH}$ & $\mathrm{H}$ & $\mathrm{H}$ & VH & $\mathrm{H}$ \\
\hline & $\begin{array}{l}\text { Increased } \\
\text { project } \\
\text { duration }\end{array}$ & $\mathrm{H}$ & $\mathrm{H}$ & $\mathrm{H}$ & M & $\mathrm{H}$ & $\mathrm{H}$ & $\mathrm{H}$ & $\mathrm{VH}$ & $\mathrm{H}$ & $\mathrm{M}$ & $\mathrm{M}$ & $\mathrm{H}$ \\
\hline & Implementation & $\mathrm{H}$ & $\mathrm{H}$ & VH & M & $\mathrm{VH}$ & M & $\mathrm{H}$ & $\mathrm{H}$ & VH & $\mathrm{H}$ & VH & $\mathrm{H}$ \\
\hline & $\begin{array}{l}\text { Lack of } \\
\text { experience } \\
\text { with PPP } \\
\text { projects }\end{array}$ & VH & VH & $\mathrm{H}$ & $\mathrm{VH}$ & VH & $\mathrm{H}$ & $\mathrm{H}$ & $\mathrm{H}$ & M & M & $\mathrm{H}$ & $\mathrm{VH}$ \\
\hline & $\begin{array}{l}\text { Project } \\
\text { uniqueness }\end{array}$ & $\mathrm{VH}$ & VH & VH & $\mathrm{VH}$ & $\mathrm{L}$ & $\mathrm{H}$ & $\mathrm{L}$ & M & M & $\mathrm{H}$ & $\mathrm{H}$ & $\mathrm{H}$ \\
\hline & $\begin{array}{l}\text { Operational } \\
\text { risks }\end{array}$ & $\mathrm{H}$ & $\mathrm{H}$ & VH & $\mathrm{H}$ & $\mathrm{H}$ & $\mathrm{VH}$ & $\mathrm{VH}$ & $\mathrm{H}$ & $\mathrm{H}$ & $\mathrm{VH}$ & $\mathrm{H}$ & $\mathrm{H}$ \\
\hline
\end{tabular}

Step 2: Use expert views for determining the Fuzzy evaluation matrix. In this step, experts assess risk criteria.

Step 3: Process expert judgments and determine the Fuzzy evaluation matrix. To do so, you should convert verbal variables into Fuzzy numbers using the rules displayed in Table 4. Then, using Eq. 5, you should conclude expert judgments and finally, determine the Fuzzy evaluation matrix using Eq. 6.
Step 4: Normalize the Fuzzy evaluation matrix and calculate the weights of risk criteria for the normalized matrix using Eqs. 7 to 11 . The Normalized Fuzzy evaluation matrix using verbal judgments and views of experts E1, E2, E3, and E4 are indicated in Table 12.

Step 5: Calculate the Fuzzy positive ideal solution (FPIS), the Fuzzy negative ideal solution (FNIS), the difference between the two solutions for each 
candidate, and the closeness coefficient for each candidate using Eqs. 12 to 15, and prioritize them as shown in Table 13.

Step 6: Determine the risk level of the project and prioritize the candidates.

After simulating these steps and considering the coefficients obtained by Fuzzy AHP for risk factors shown in Table 3, Fuzzy TOPSIS is executed for the weights and according to Table 13, risk levels of candidates $A_{1}, A_{2}$, and $A_{3}$ are $0.353,0.391$ and 0.412 respectively. In addition, according to the same table, $A_{1}$ and $A_{3}$ have the lowest and highest amount of closeness coefficient respectively.

1) Prioritization of 10 risk factors is shown in Fig. 4. As can be seen, performance, increased tolls, politics, government interference, government funding, market, payment, and implementation risks have the highest to lowest influence, respectively, on determining the overall risk. Also, the new risks (increased freeway tolls, increased costs of implementation, and increased project duration) are taken into consideration in this study. 2) Our four risk categories include basic and political, economic, environmental and social, and technical risks of the project, and are based on categorizations of earlier studies. According to Fig. 3 , the weights of these main risk factors are $28.53 \%$, $26.36 \%, 7.25 \%$, and $37.85 \%$ respectively. Therefore, all these categories influence the project's overall risk level.

3) Unlike analyses carried out in earlier studies [22], the proposed method determines the overall risk level of the freeway PPP project using Fuzzy AHP while other studies focus on risk allocation between public and private sectors in different areas. In the present study, we analyzed various risks relating to freeway PPP projects, made use of Fuzzy AHP for prioritizing risk factors and their sub-criteria, and in the following section, we will select the fittest candidate for the execution of Saveh-Salafchegan Freeway PPP Project using Fuzzy TOPSIS.

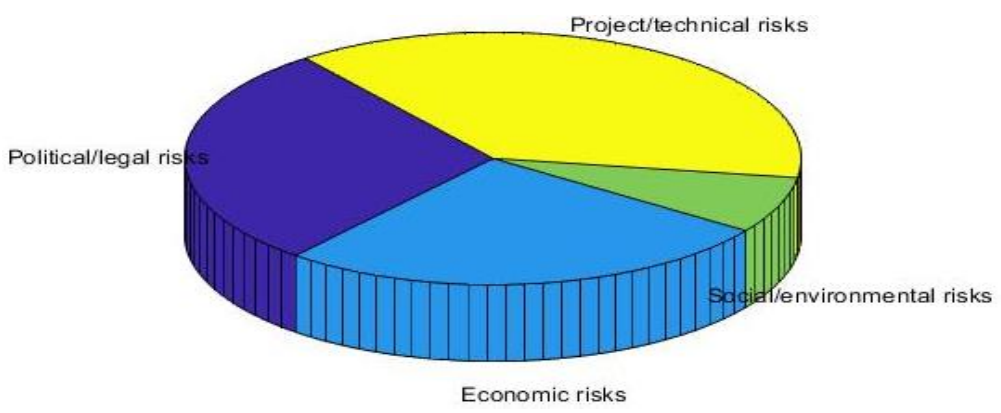

Fig. 3. Main risk factors and their weights

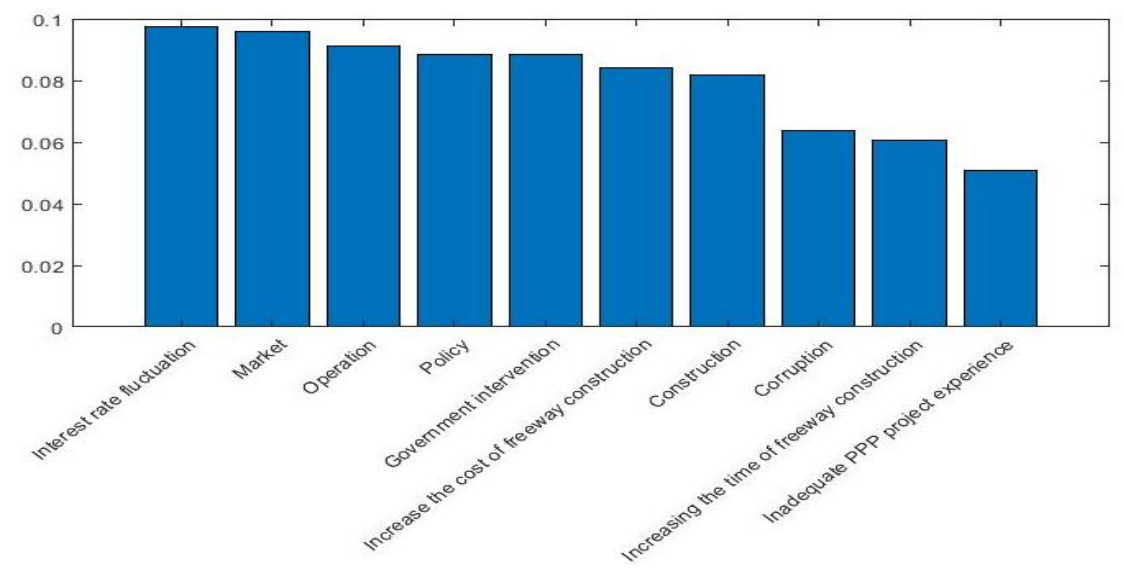

Fig. 4. Prioritization of 10 important risks for determining the overall risk of the freeway project 
Table 12 Normalized Fuzzy evaluation matrix according to weights allocated using expert views

\begin{tabular}{|c|c|c|c|c|}
\hline $\begin{array}{l}\text { Main risk } \\
\text { (criteria) }\end{array}$ & Risk factors & Candidate A1 & Candidate A2 & Candidate A3 \\
\hline \multirow{4}{*}{$\begin{array}{l}\text { Basic and } \\
\text { political risks }\end{array}$} & Politics & $(0.067,0.048,0.034)$ & $(0.053,0.040,0.034)$ & $(0.050,0.037,0.031)$ \\
\hline & $\begin{array}{l}\text { Government } \\
\text { interference }\end{array}$ & $(0.061,0.045,0.038)$ & $(0.059,0.045,0.041)$ & $(0.066,0.049,0.038)$ \\
\hline & $\begin{array}{l}\text { Government } \\
\text { funding }\end{array}$ & $(0.043,0.031,0.029)$ & $(0.059,0.046,0.034)$ & $(0.054,0.041,0.032)$ \\
\hline & Corruption & $(0.042,0.031,0.024)$ & $(0.040,0.033,0.029)$ & $(0.057,0.040,0.029)$ \\
\hline \multirow{4}{*}{ Economic risks } & Market & $(0.052,0.039,0.030)$ & $(0.048,0.036,0.028)$ & $(0.060,0.042,0.030)$ \\
\hline & $\begin{array}{l}\text { Interest rate } \\
\text { fluctuations }\end{array}$ & $(0.043,0.033,0.028)$ & $(0.060,0.043,0.031)$ & $(0.053,0.041,0.031)$ \\
\hline & Income & $(0.047,0.030,0.021)$ & $(0.058,0.032,0.022)$ & $(0.058,0.032,0.022)$ \\
\hline & Payment & $(0.025,0.017,0.013)$ & $(0.038,0.021,0.015)$ & $(0.038,0.021,0.015)$ \\
\hline \multirow[b]{2}{*}{$\begin{array}{l}\text { Environmental } \\
\text { and social risks }\end{array}$} & $\begin{array}{l}\text { Increased } \\
\text { freeway tolls }\end{array}$ & $(0.050,0.037,0.029)$ & $(0.057,0.046,0.037)$ & $(0.057,0.046,0.037)$ \\
\hline & $\begin{array}{l}\text { Lack of } \\
\text { supporting } \\
\text { equipment }\end{array}$ & $(0.056,0.042,0.033)$ & $(0.051,0.039,0.033)$ & $(0.051,0.039,0.033)$ \\
\hline \multirow{7}{*}{ Technical risks } & Performance & $(0.067,0.047,0.034)$ & $(0.055,0.040,0.028)$ & $(0.054,0.040,0.031)$ \\
\hline & $\begin{array}{l}\text { Increased costs } \\
\text { of } \\
\text { implementation }\end{array}$ & $(0.067,0.048,0.034)$ & $(0.051,0.037,0.034)$ & $(0.060,0.044,0.034)$ \\
\hline & $\begin{array}{l}\text { Increased project } \\
\text { duration }\end{array}$ & $(0.057,0.041,0.030)$ & $(0.048,0.036,0.027)$ & $(0.064,0.045,0.032)$ \\
\hline & Implementation & $(0.064,0.048,0.037)$ & $(0.064,0.048,0.038)$ & $(0.055,0.041,0.035)$ \\
\hline & $\begin{array}{l}\text { Lack of } \\
\text { experience with } \\
\text { PPP projects }\end{array}$ & $(0.045,0.033,0.031)$ & $(0.053,0.039,0.031)$ & $(0.063,0.047,0.036)$ \\
\hline & $\begin{array}{l}\text { Project } \\
\text { uniqueness }\end{array}$ & $(0.020,0.015,0.015)$ & $(0.058,0.032,0.022)$ & $(0.030,0.022,0.016)$ \\
\hline & Operational risks & $(0.055,0.041,0.032)$ & $(0.050,0.037,0.032)$ & $(0.055,0.041,0.032)$ \\
\hline
\end{tabular}

Table 13 FPIS and FNIS Distances, closeness coefficient and prioritization of the available candidates for the development of the Saveh-Salafchegan freeway PPP project

\begin{tabular}{ccccc}
\hline PPP Candidates & $\boldsymbol{d}^{+}$ & $\boldsymbol{d}^{-}$ & $C C$ & Ranking \\
\hline$A_{1}$ & 0.413 & 0.241 & 0.369 & 1 \\
$A_{2}$ & 0.385 & 0.268 & 0.411 & 2 \\
$A_{3}$ & 0.384 & 0.279 & 0.421 & 3 \\
\hline
\end{tabular}




\section{Conclusion and suggestions for further studies}

The current paper proposes a new hybrid MCDM approach for selecting a suitable private company to execute Saveh-Salafchegan freeway PPP Project. By analyzing literature review and evaluating expert views, first of all, the project's risk factors are identified, then a new approach is used to prioritize these factors, and finally, a new evaluation model is proposed for selecting the best executor company of the project. The proposed model is built using data gathered by a leading company known for its infrastructure projects in Iran. In addition, in the present study, we have used fuzzy AHP approach to prioritize project risks. In this approach, the relative importance of various risks helps us prioritize them. We have also employed fuzzy TOPSIS to select the best candidate company for the execution of the PPP project. Although, according to the results obtained in this paper, the private company with the least amount of risk was selected to execute the project, the limitation of this paper is that the relationship between the risks is not taken into account. Therefore, it is suggested to use other MCDM methods such as: ANP instead of AHP for future research.

\section{Declaration of conflicting interests}

The author(s) declared no potential conflicts of interest with respect to the research, authorship, and/or publication of this article.

\section{References}

[1] Zhang X (2005). Critical success factors for publicprivate partnerships in infrastructure development. Journal of Construction Engineering and Management 131(1):3-14.

[2] Hatami-Marbini A, Kangi F (2017). An extension of fuzzy TOPSIS for a group decision making with an application to Tehran stock exchange. Applied Soft Computing 52:1084-1097.

[3] Verweij S, Teisman GR, Gerrits LM (2017). Implementing public-private partnerships: How management responses to events produce (un)satisfactory outcomes. Public Works Management \& Policy 22(2):119-139.
[4] Li J, Zou PX (2011). Fuzzy AHP-based risk assessment methodology for PPP projects. Journal of Construction Engineering and Management 137(12):1205-1209.

[5] Xu Y, Chan AP, Yeung JF (2010). Developing a fuzzy risk allocation model for PPP projects in China. Journal of Construction Engineering and Management 136(8):894-903.

[6] Mousavi SM, Tavakkoli-Moghaddam R, Azaron A, Mojtahedi SMH, Hashemi H (2011). Risk assessment for highway projects using jackknife technique. Expert Systems with Applications 38(5):5514-5524.

[7] Tang W, Zhang F, Ye Z, Li J (2011). Research on risk evaluation in urban rail transit project. Procedia Engineering 15:5094-5099.

[8] RezaValipour A, HadiSarvari N, Noor NM, Rashid ASA (2013). Analytic network process (ANP) to risk assessment of gas refinery EPC projects in Iran. Journal of Applied Sciences Research 9(3):1359-1365.

[9] Bing L, Akintoye A, Edwards PJ, Hardcastle C (2005). The allocation of risk in PPP/PFI construction projects in the UK. International Journal of Project Management 23(1):25-35.

[10] Turskis Z, Gajzler M, Dziadosz A (2012). Reliability, risk management, and contingency of construction processes and projects. Journal of Civil Engineering and Management 18(2):290-298.

[11] De Lemos T, Eaton D, Betts M, de Almeida LT (2004). Risk management in the Lusoponte concession - a case study of the two bridges in Lisbon, Portugal. International Journal of Project Management 22(1):63-73.

[12] Zhang Y, Han Q (2017). Development of electric vehicles for China's power generation portfolio: a regional economic and environmental analysis. Journal of Cleaner Production 162:71-85.

[13] Vivekh P, Sudhakar M, Srinivas M, Vishwanthkumar V (2016). Desalination technology selection using multi-criteria evaluation: TOPSIS and PROMETHEE-2. International Journal of Low-Carbon Technologies 12(1):24-35.

[14] Zhang X, Liang Y, Liu W (2017). Pricing model for the charging of electric vehicles based on system dynamics in Beijing. Energy 119:218-34.

[15] Mahdevari S, Shahriar K, Esfahanipour A (2014). Human health and safety risks management in underground coal mines using fuzzy TOPSIS. Science of the Total Environment 488:85-99. 
[16] Estay-Ossandon C, Mena-Nieto A, Harsch N (2018). Using a fuzzy TOPSIS-based scenario analysis to improve municipal solid waste planning and forecasting: a case study of Canary archipelago (1999-2030). Journal of Cleaner Production 176:1198-212.

[17] Onu PU, Quan X, Xu L, Orji J, Onu E (2017). Evaluation of sustainable acid rain control options utilizing a fuzzy TOPSIS multi-criteria decision analysis model framework. Journal of Cleaner Production 141:612-625.

[18] Rostamzadeh R, Ghorabaee M K, Govindan K, Esmaeili A, Nobar HBK (2018). Evaluation of sustainable supply chain risk management using an integrated fuzzy TOPSIS-CRITIC approach. Journal of Cleaner Production 175:651-669.

[19] Wang YM, Luo Y, Hua Z (2008). On the extent analysis method for fuzzy AHP and its applications. European Journal of Operational Research 186(2):735-747.

[20] Chang DY (1996). Applications of the extent analysis method on fuzzy AHP. European Journal of Operational Research 95(3):649-655.

[21] Khameneh AH, Taheri A, Ershadi M (2016). Offering a framework for evaluating the performance of project risk management system. Procedia-Social and Behavioral Sciences 226:8290.

[22] Islam MS, Nepal MP, Skitmore M, Attarzadeh M (2017). Current research trends and application areas of fuzzy and hybrid methods to the risk assessment of construction projects. Advanced Engineering Informatics 33:112-131.

[23] Osei-Kyei R, Chan AP (2017). Risk assessment in public-private partnership infrastructure projects: Empirical comparison between Ghana and Hong Kong. Construction Innovation 17(2):204-223.

[24] Ma X, Chen D, Ji J (2016). EV charging infrastructure PPP project risk analysis for private sector. Modern Management Science 8:3-5.

[25] Wu Y, Li L, Xu R, Chen K, Hu Y, Lin X (2017). Risk assessment in straw-based power generation public-private partnership projects in China: A fuzzy synthetic evaluation analysis. Journal of Cleaner Production 161:977-990.

[26] Kumar L, Jindal A, Velaga NR (2018). Financial risk assessment and modeling of PPP based Indian highway infrastructure projects. Transport Policy 62:2-11.

[27] Cheung E, Chan AP (2011). Risk factors of publicprivate partnership projects in China: Comparison between the water, power, and transportation sectors. Journal of Urban Planning and Development 137(4):409-415.

[28] Saaty TL (1988). What is the analytic hierarchy process? In Mathematical models for decision support, Springer, 109-121. 